\author{
Juhan Maiste
}

\title{
ART AND TRUTH
}

It is a divine power that moves you, as a "Magnetic" stone moves iron rings. ... This stone not only pulls those rings, if they're iron, it also puts power in the rings, so that they in turn can do just what the stone does - pull other things - so that there's sometimes a very long chain of iron pieces and rings, hanging from one another. And the power in all of them depends on this stone. In the same way, the Muse makes some people inspired herself, and then through those who are inspired a chain of other enthusiasts is suspended.

Plato, Two Comic Dialogues: Ion and Hippias Major, trans. Paul Woodruff (Indianapolis: Hackett Publishing, 1983), 24.

What inspired me to write this essay was a recent interview with artist Olav Maran, in which he maintained, while summing up the credo of his art, the following:"Truth matters more to me than art." ${ }^{1}$ The latter being a relatively rare statement of truth by an artist which, however, reflects the willingness of the creative person to see the aims of his work on a deeper level than the formal one, beyond the characteristic coordinate network shaped by the line, form and colour. Yet impelling one from this point on to think further. To inquire about the two mutually connected, yet in several senses opposite categories - about being and the projection of this in our imagination, in which, as Maran indirectly expresses, the two opposite poles of our nature clash - to be (Latin:

DOI: http://dx.doi.org/10.12697/BJAH.2014.7.07

Translation by Reet Sool

1 Andres Eilart, „Olav Maran: tõde on minu jaoks olulisem kui kunst“, Eesti Päevaleht, 1.10.2013. 
Fig. 1. Olav Maran, "Still Life with Brown Drapery". Oli, canvas, 1988 (AME).

Fig. 2. Olav Maran, "Still Life with Coconuts and Seashells". Oil, fibreboard, 1989 (AME). 
esse) and essence (Latin: essentia), one of which leads to pure knowledge and the other to the existence that reveals this. The idea of the stone is not hidden in its angularities that we can experience somewhere on the edge of a cliff while gazing at the wastness, nor in the image of those in the painting, but in the contact of the idea with the primary principle which has been described since the antiquity as something that cannot finally or through one concrete knowledge be described, which is invisible, truth and idea at the same time, that opens itself as the air between the eye and the object, and which, according to Plato, can be described "as intraocular fire that produces the visual image".

The thing and the image of this belong together. Truth does not comprise either in the external or the internal, it is not deeper or higher. Instead it is some special environment in which things find their own form and will become existing for us. It is not earth or sky, void or some palpable substance. Instead, it is transparency, "something else ... in which transparency is no longer potential, but becomes actual, so that that bodies separated from the observer by the medium become visible." 3 Something that allows us to place things that we can imagine but which we cannot ever embrace in their entirety and finality, into a frame and then hang it as a picture on the wall. A picture is no landscape, least of all nature, but an independent reality instead, which, as an independent created substance, possesses qualities that do not exist in the so-called real life, or if they do, then never in the consistence of truth that we imagine as existing outside the reality beyond us.

While discussing the topics of art and truth we are, actually, discussing the much more profound epistemological questions. Something that might not come into an artist's mind or be explained in its conflicting dialectic nature while he is painting a picture but, instead, leads us on the one hand towards my own and on the other hand not my own problems of self-definition, making room for philosophy and, finally, instead of philosophy, for religion. However, what is it that we still believe - either matter or spirit, existence or transcendence, physics or metaphysics - this is the question that not everyone of us solves entirely differently, yet still according to his preconditions of birth and life experience. A catholic will be catholic, an orthodox stays orthodox and a lutheran still

2 David C. Lindberg, Theories of Vision from Al-Kindi to Kepler (Chicago \& London: The University of Chicago Press, 1976), 5.

3 Ibid., 7. 
lutheran even when they themselves would not realize or admit this to the end. This is so even though his flying thoughts would be connected with philosophy, music or figurative arts. As much as we are free, we are in our imagination the prisoners of the time and space that surround us and dwell within us, being bound to something that different schools of philosophy and religions interpret differently, something that has brought with "the schism with which we are concerned by developing abstract representations of space, among them the Cartesian notion of space as absolute, infinite res extensa, a divine poetry which may be grasped in a single act of intuition because of its homogeneous isotropic character." 4

Although intriguing, philosophy is still not the topic of the present writing. Neither shall we consider the various fundamental problems of cognizing the possibilities and ways of our world (which, however, are hard to ultimately ignore -no matter whatever we would assert on the topics of truth). Instead, we shall be concentrated on one narrower focus which ultimately brings us back to the question we asked at the beginning of our article - are art and truth separable or should we in this case use notions that refer simultaneously and in one breath to the two qualities of substance. Does the rainbow that has been pondered upon over and over again since the antiquity and renaissance, and completing with the theories of the modern world of optic reflection, belong to the domain of science and its methods of analysis, or do we deal with the phenomena of art that possesses the characteristic attributes of visual reality that first and foremost nourish our imagination, hurling a new reality into our senses that, for example, on the paintings of William Turner or, say, Claude Monet, cannot be summarized with any argument belonging to the sphere of earthly thinking? What is light and what is art? What is this being that gives a physical dimension (Gr:

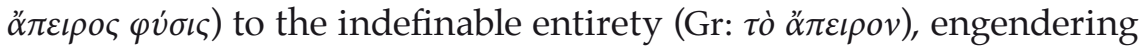
ever more new forms in us, changing the infinite into concrete finality and the latter in the form of a work of art in turn into new and again logically indefinable infinity that dwells in its own reality - the reality that nobody else is aware of.

4 Henri Lefebvre, The Production of Space, trans. by Donald Nicholson-Smith (Oxford: Blackwell Publishing, 1991), 14. 
Sunlight in the air is an instrument of soul. And the other way round. As Plotinus observed, the soul is part of the light that as a dichotomic unity will bind together the two different halves of the objective and the subjective. The utmost question at that is how and by which matrixes we explain the world that makes itself known and that we get to know, and that recedes like the truth the nearer to which we get. Truth is a mirage and truth is the light that according to Augustine contained as an invisible and not-created potential in the essence of God, being the source for all other visible light, to all that proceeds from the archetype and is the repetition of this. ${ }^{5}$ And all this both in the area of things and imagination, revealing itself as an artistic image - as a rainbow in the painting of Jan van Eyck's "Adoration of the Mystic Lamb", acquiring a holy and at the same time also a definable meaning in the concrete iconological system. Body and soul - as well as their images both in our fantasies and art - then in a new and mediated form are not the dualistically distinguishable components of the one and the same principle, in which knowledge means being well informed either with the earthly or else with the celestial substance. Instead, it means the ability given to us to create the worlds we see and perceive. Just as truth, art, too, is everywhere, in everything small and big, in the final and infinite, concrete and abstract, in the sphere of forms and infinity, which Maran apparently keeps in mind in his interview.

\section{BEAUTY AND LIGHT}

What is light and what is its source? How does the world project itself on the retina of our eye, in our senses and our consciousness directed by the intellect, and how is it expressed in the new created-artistic reality? These are questions that could be answered in very different ways. In the publication ${ }^{6}$ that appeared a few years ago at the University of Tartu and which dealt with the philosophical problems of Truth, the presumption of writing about truth is its logical ground and the method of linguistic analysis which, according to Gottlob Frege, allows one to distinguish the epistemic truth from the non-epistemic concept, leaving

5 Augustine, Concerning the City of God against the pagans, 10.2 (London: Penguin Books, 1984), 374-375.

6 Truth, ed. by Roomet Jakapi, Daniel Cohnitz, Eduard Parhomenko, Kadri Simm, (Studia Philosophica Estonica, vol. $1.1 \&$ 1. 2, Tartu, 2008). 
art a possibility to find its own method in the fictional reality peculiar to it and through its own representations. ${ }^{7}$ No matter which our decision of the world of ideas is -whether ideas are before or after things (ante res or post res), art is the mediator between the object and subject, belonging together both with the first and the second postulate. The sum or the artistic truth does not depend on the sequence of the components. Instead, it represents a beginning which, if once kindled, will flare every time when the artist shapes a next/new work of art by means of the techne (Gr: $\dot{\eta} \tau \dot{\varepsilon} \chi v \eta$ ) that he/she once mastered.

At the same time, "the frontier between formless sensibilia and the meaningful conceptions of the mind is an empty space that sometimes is called plasma and the actions inside this territory plasmatic" ${ }^{\prime \prime}$. If you touch it, it seems as if you touched emptiness which really does not exist, yet which still exists. Something that changes "the loss of the real" actual, which according to Jacques Derrida "emerges from the parergonal ground into the other ", leaving the cortex - form that covers art - to dry on some wall of a museum, and focusing, first and foremost, on the impulse that art sustains. Something that cannot be unravelled or placed on the weaving loom. Every picture is a secret, a puzzle, the message of which in an interview by Claude Levi-Strauss to Paolo Caruso rather hides than opens ${ }^{10}$, even though offering an opportunity to speak about the frame that surrounds it, the style, context and narrative and the biographies of artists, yet which in any other language than art itself remains in its essence concealed, requiring the knowledge that takes us to the odysseys somewhere in the depths of esse, to the bottom of the ocean where, amid the bones of the Titanic, Pandora's chest is to this day still hidden. In order to open it, we need a secret code - a key, the shape and form of which depend on the one hand on the material it is made of, and on the other hand on the gate that art is summoned to open.

The relation between parergon and ergon is the relation between the world and myself, the seeming and the rhetorical and the real or religious

7 Gerald Vison, „Indeed,"Really”, In Fact,"Actually“", Truth, 71.

8 Mark A. Cheetham, Kant, Art and Art History. Monuments of Discipline (Cheetham: Cambridge University Press, 2001), 25.

9 Jacques Derrida, „La vérité en peinture“, The Truth in Painting (Chicago, London: University of Chicago Press, 1987), 61.

10 Peeter Torop, „Lugeja olemine kultuuris“, Umberto Eco, Lector in Fabula, ed. by Ülar Ploom (Tartu: Tartu Ülikooli Kirjastus, 2005), 4. Later Eco returned to the dichotomy open-close, giving it a new connotation in his lecture held at Tartu University on 29.09.2009, see Umberto Eco's video lecture http://www.ut.ee/564132 (viewed on 08 July 2014). 
which, according to the very often quoted train of thought of the founder of the phenomenological epistemology Immanuel Kant, "supplies us with intuitions" (German: Anschauungen). These intuitions become through the imagination (German: Einbildungskraft) to find the understanding (German: Verstand) and hence arise conceptions (German: Begriffe). ${ }^{11}$ It is only through the imagination that the external finds a place in our inner being because in no other ways can objects be given to us. Very different forces meet in art: "artistic and natural production, aesthetic and teleological judgement mutually illuminating each other. ${ }^{\prime \prime 2}$ In the case of art we deal on the one hand with the repetition of the existing reality and on the other hand with a new reality that is born in the relation with mimesis and convention and their representation through the artist's will and genius. "Something represents something else, if and only if, the former mimics the latter in some relevant way."13

In the most broad sense, art does function like a gate, which by two realities - idea and form, shapes a new reality - the kind that according to Heidegger gives substance to "what simultaneously brings the unsayable as such into the world." ${ }^{14}$ What is said about poetry is basically true of the visual arts as well. "A building, a Greek temple, portrays nothing. It simply stands there in the middle of the rock - cleft valley. The building encloses the figure of the god, and in this concealment lets it stand out to the holy precinct through the open portico."15

At the moment when within and above what can be measured and touched by the hand, an invisible infinity opens itself which, when unleashed (German: erscheinen), turns the vague into albescent, the dim substance into light, unleashing in us the desire "of writing in a language which shows nothing, describes nothing and represents even less."16 Even a picture that depicts nothing or depicts this differently from the depicted, may be connected with truth that changes the theorem about the forwarder of information and the recipient of information, a simple

11 Immanuel Kant, „Critique of Pure Reason“, Immanuel Kant, The Transcendental Doctrine of Elements, B. 33, trans. F. Max Müller, ed. Allen Wood (New York: Modern Library, 2001), 42.

12 Ernst Cassirer, Kant's Life and Thought, trans. James Haden (New Haven: Yale University Press, 1981) 273.

13 Roman Frigg, Matthew C. Hunter, Beyond Mimesis and Convention (Dordrecht, Heidelberg, New York: Springer, 2010), xv.

14 Martin Heidegger, The Origin of the Work of Art, Poetry, Language, Thought, transl. Albert Hofstadter (New York: Perennial Classics/HarperCollins, 2001), 71.

15 Ibid., 40.

16 Derrida, La vérité en peinture“, 3. 
classical reception theory, more complicated than at first thought. Which questions the credibility of both the famous statement of Cézanne: "I owe You the truth in painting and I will tell it to You", as well as the considerably milder attempt of Maran-to divide the two levels that have stuck together.

Is it possible to retell pictures, and if so, what is the use of this? What in a form of "the presentation of representation, presentation of the presentation, representation of the representation", asks Derrida. ${ }^{17}$ Does truth belong to the same category as the notions "grammatical" and "syntactical", and even "semantic normality", or is the truth somewhere else, which makes the search for the so-called "the truth of truth" controversial and via the algorithms of reason almost impossible. "Parergon has a thickness, a surface which separates them not only (as Kant would have it) from the integral inside, from the body proper of the ergon, but also from outside, from the wall, on which the painting is hung, from the whole field of historical, economic, political inscription in which the drive to signature is produced. No "theory" no "practice" can intervene effectively in this field if it does not weigh up and bear on the frame, which is the decisive structure of what is at stake, at the invisible limit to (between) the interiority of meaning (put under shelter by the whole of hermeneutics, semiotics, phenomenological and formalist tradition) and (to) all the empiricism of the extrinsic which, incapable of either seeing or reading, miss the question completely."18

\section{ART AND LIGHT. FROM THE PERSPECTIVE TO HOLY FIRE}

How are the moon and stars born in the sky? How does the rainbow rise into the sky on the painting of the bowing sheep by Jan van Eyck? "Speculations about the rainbow can be traced almost as far back as written records go."19 Either in one way or another, the discussion of the visible world or of seeing in general -in its abstractly philosophical or the concretely practical way -takes its beginning in the ability of $e i$ dos to find itself a shape by means of forms. In one way or another both senses as well as their recipient eye are involved here, giving a place to

17 Ibid., 4-6

18 Ibid., 60

19 Lindberg,Theories of Vision from Al-Kindi to Kepler, 5. 
the light "in the mirroring that takes place in an eye which is seen, but in that which sees" ${ }^{\prime 20}$ Where then?

In principle, the question of seeing could be divided into two big parts -what is light and how it reflects in our consciousness. When the first one belongs to the domain of epistemological knowledge, then the second one to the domain of cognitive reception which, formally taken, differ from one another, yet do not exclude one another, giving way to the one and the same entirety, in which the intellect characteristic of human soul abstracts the intelligibility of all the images his eye senses and translates them by imagination of sense perceptions into immaterial phantasma (Gr: $\tau \dot{c} \varphi \alpha \dot{v} \tau \alpha \sigma \mu \alpha) .{ }^{21}$ The eye is important, through the eye we can participate in the world which in our imaginations lies on the other side of the space shaped by my own "I". The omnipotence of the eye is a presumption for creating a new - artistic reality, which for the ancient Greeks meant the regulation of chaos at the moment when the chariot of Helios would take off the mountain of Parnassos and which, according to Anaximander, is a central event in the formation of Greek cosmos (Gr: $\delta$ кó $\sigma \mu \circ))^{22}$

The Christian tradition takes over the idea of light from Greece, fusing the external and internal - universality and the soul. According to the 12th century scholastic thought "the sunlight with its luminous and visual rays" will unite the celestial and the mundane, the eye and the starlight in a way that enables the light "to be instantly here and instantly there. ${ }^{23}$ Like the blue anemones come up under the forest in spring, and the maples turn multicoloured in autumn, we in our thoughts turn back to light and fire, which catches fire for the second time in the phantasy of the artist, something that has been given to us both in the shape of the geometrical image of the universe, as well as the exact mathematical formula (as Euclid and Pythagoras visualized it) and as a revealed integral picture - a world full of colours and passions, and the entire drama of existence. Which," changes "holy madness" the reality that exists in the artist's imagination (It.: realita existenziale) into pure reality (It.: realita pura). "The constitution of the object is not mimesis, meaning

20 Aristotle, „De sensu“, 2, 438a5, De sensu and de memoria, text and translation with introduction and commentary by George Robert Thomson Ross (Cambridge: University Press, 1906), 53.

21 Lindberg, Theories of Vision from Al-Kindi to Kepler, 12.

22 Indra Kagis McEwen, Socrates' Ancestor. An Essay on Architectural Beginnings (Cambridge, Massachusetts: MIT Press, 1993), 24-25.

23 Guillaume de Conches, „Philosophia mundi“, Reginald L. Poole, Illustrations of the Medieval Thought and Learning (London: Society for Promoting Christian Knowledge, 1920), 298. 
the form of the image as figurativeness is neither the conformation of what is represented, nor that of the object produced as an instrument of its manifestation, whether it is a painting, a sculpture, a relief or an architectural construction. Its essence lies in the divorce with existence, in negativity." 24

But what is phantasy and how is it associated with the facts that light has made visible, and how these, in their own turn, are expressed in art? What forces also in the absence of light or in the conditions of the non-presence of this to create light, which, on the one hand, is a trace in memory (Gr: $\tau \dot{o} \varepsilon i \delta \omega \lambda o v)$ and an image that repeats it (Gr: $\dot{\eta} \varepsilon \dot{\varepsilon} \kappa \omega \dot{v})$, and on the other hand a fabrication, in which case "the guiding idea in this sense is the eidetic difference between two aims, two intentionalities: the first, that of imagination, directed toward the fantastic, the fiction$\mathrm{al}$, the unreal, the possible, the utopian, and the other, that of memory, that of memory directed toward prior reality, priority, constituting the temporal mark par excellence of the thing remembered, of the remembered as such." 25

In order to create something, we need pushing off, a liberating explosion that beginning with the works of the theoreticians of the Renaissance we comprehend as the activeness of the genius and the creative passion of him, which places the artist to the position of the demiurge, whose every stroke of the brush as the creator of a new reality we appreciate as a word from the prophet's lips, where the primeval quarrel (a term of Martin Heidegger) between heaven and earth, object and subject, intuition and logic is fought, and from which the work of art leaves as mentally cleansed, declaring itself in the unique and legitimate language of symbols in the form of prepresentation in a new quality of an image. In a process like this that is called art, beauty acquires a double meaning which, like the core of the things, is something that lies at the ground

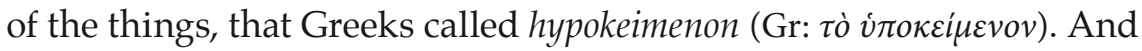
which gives to the piece of the rock, in addition to its peculiar mass, colour, etc. - to all the accumulation of properties - a central point "around all these properties are assembled." ${ }^{26}$ What is this? we ask.

24 Paul Philippot, „The Phenomenology of Artistic Creation according to Cesare Brandi“, Cesare Brandi, Theory of Restoration, ed. Giuseppe Basile, trans. Cynthia Rockwell (Rome: Instituto centrale per il restauro; Florence: Nardini, 2000), 30.

25 Paul Ricoeur, Memory, History, Forgetting, trans. Kathleen Blamey, David Pellauer (Chicago. London: The University of Chicago Press, 2006), 6.

26 . Heidegger, The Origin of the Work of Art, Poetry, Language, Thought, 22 


\section{ART AS STONE}

If an action is performed in a fine way, the world becomes fine ( $\mathrm{Gr}$ :

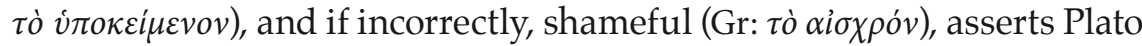
in his Symposium. ${ }^{27}$ Throughout the ages the road to beauty has been searched for, and two ways have been found for this: one of these proceeds through the balance of proportion, harmony and colour, the second one through experience, which via art presents itself as the transfiguration that is the foundation of all harmony - the soul of the soul, from

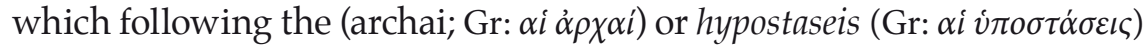
at a lower level, the World soul and individual souls derive. ${ }^{28}$ Beauty is something that opens through prayer and redemption which, as we continue reading Maran, is the very aim of the artist. Something that manifests itself as an apocalyptic revelation, making Christ's face glow even in the most savage scenes of suffering. Also changing that which is not seemingly beautiful into beautiful, the invisible into visible, using for this purpose a mirror that is placed at a right angle. "Likewise, if the mirror be placed opposite the object, there is no more image; and if the mirror be withdrawn or badly adjusted, there is no more image, though the luminous object continue to act. Likewise, when that faculty of the soul which represents to us the images of discursive reason and of intelligence is in a suitable condition of calm, we get an intuition - that is, a somewhat sensual perception there of - with the prior knowledge of the activity of the intelligence, and of discursive reason." ${ }^{29}$

Although beauty and truth are not synonyms, they are still very close notions. In order to reach them both, activity is assumed, the latter in its own turn presumes the co-action of intellect and intuition which, while contributing both to one and the other side, give a chance to define them differently -both as science (geometry and mathematics) and as art. It goes without saying that both of these have their own instruments-besides eyes the telescopes, brushes and nowadays computers that all together allow us to see contours in nature which enable us to put together the whole picture, and from this, in its own turn, a double picture via the artistic act, which resembles but is not the same as what

27 Plato, „Symposium“, 181, a 4 - 5. Platon, Werke, III (Darmstadt: Wissenschaftliche Buchgesellschaft, 1990), 239.

28 Kevin Corrigan, Reading Plotinus. A Practical Introduction to Neoplatonism (West Lafayette: Purdue University Press, 2005), 23.

29 Plotinus, „Enneads“, I, IV, 10, Complete works, ed. Sylvian Gurthrie (London: Bell, 1918) 
Fig. 3. Peeter Laurits, "Atlas of Heavens 28". Digital print. 2002.

is in a hidden form existent in the rough stone (Michelangelo) but which will achieve the value of its own only by contact with the higher principle, who through "the intellectual beauty of the Authentic Intellect will be able to come to understand the Transcendent of that "Divine Being", allowing Plotinus a possibility to assert that "the stone brought under the artist's hand to the beauty of form is beautiful not as stone - for so the crude block would be as pleasant - but in virtue of the form or idea introduced by the art. The beauty, therefore, exists in a far higher state in the art; for it does not come over integrally into the work; that original beauty is not transferred; what comes over is a derivative and a minor: and even that shows itself upon the statue not integrally and 


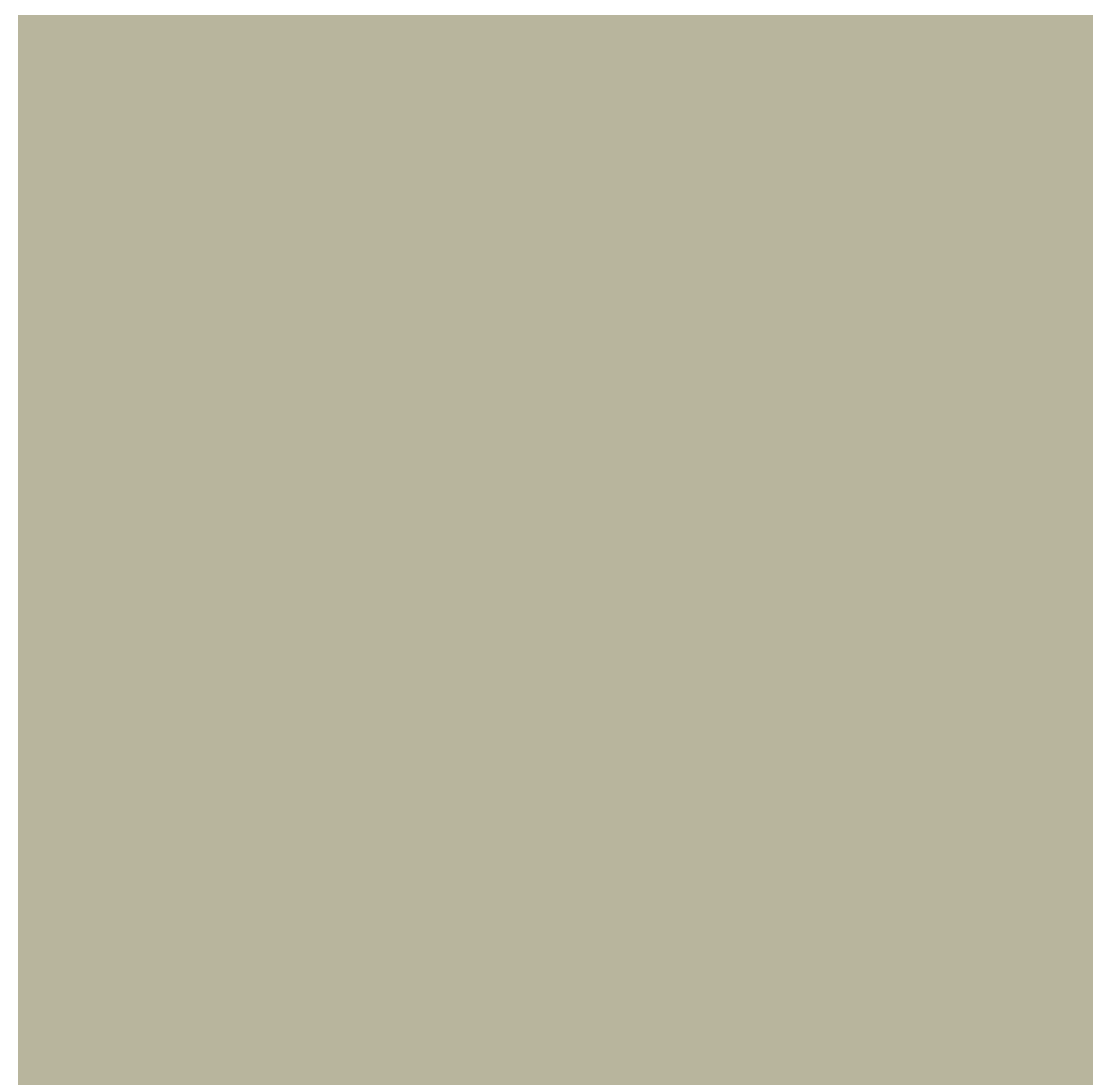

Fig. 4. Peeter Laurits, "Atlas of Heavens 39". Digital print. 2008.

with entire realization of intention but only in so far as it has subdued the resistance of the material." 30

The reason for the birth of art is light that the artist carries out, giving birth to the artistic reality which in its absolute beauty is neither born nor dies (it is the works of art that die and are born), that are always there, that in the paintings of Caravaggio falls down "the cellar-door", giving a chance to the soul to penetrate through the darkest surface and do its business there in its contemplative solitude. Something that makes the water shine like iridescent crystal proceeding from the throne of God and the Lamb in the painting of Jan van Eyck. In a way that can-

30 Ibid., V, 8, 1. 
not be ever repeated by anybody. Something that can be reached only by devotion ("redemption", as Maran put it) or else by the love of beauty that gives light to the world "aimer la beauté, c'est voir la lumière"31, as Victor Hugo has put it.

A picture can be read in two ways - as a divine revelation and the coming in sight of the absolute through the Creator's work, or the other way round, as our own will for art (German: Kunstwollen), which, according to Heinrich Wölfflin, forces the artist to paint with his/her own blood. ${ }^{32}$ Differently from its twin brother - science, the borders of which were largely established during the Age of Enlightenment, and the proclamation of truth of which is always more truthful today than it was yesterday, and tomorrow better than today, art does not contain in itself the notion of progress. The cave paintings of Lascaux and the frescos of the Sistine Chapel do not differ from one another not just by their artistic message, but only by the subject they deal with, and the text. A work of art is never more true or more wrong, even not better or worse, but always the same, constantly present in the way Plato's eidos or Plotinus's "The One", producing light and reverberating this via the spirit that has become flesh. Light is what has helped both to build the Great cathedrals of Europe and to develop the foundations of empirical science, inspiring Roger Bacon in his philosophy of light as well as manufacturing optical instruments to measure this. Something that by the end of the Middle Ages enabled man "not only to see all mirabilia with their eyes, but to transform them into the visual image." 33 In order to see, man needed eyes. In order to place that which had been seen into a credible system, man needed both the central perspective invented by Leon Battista Alberti, as well as the camera obscura constructed by Filippo Brunelleschi, that rendered the Vitruvius manuscript refound by Poggio Bracciolini the significance of illuminated truth and guidance.

31 Victor Hugo, Les Misérables, Tome V, Chapitre XX, (The Project Gutenberg E-Book, http://www. gutenberg.org/files/17519/17519-h/17519-h.htm\#Chapitre_XX (viewed on 08 July 2014)

32 Heinrich Wölfflin, Principles of Art History: The Problem of the Development of Style in Later Art, trans. Marie Donald Mackie Hottinger (New York: Corier Dover Publications, 1950), 1.

33 Jacques Le Goff, The Medieval Imagination, trans. Arthur Goldhammer (Chicago, London: The University of Chicago Press, 1985), 27. 


\section{THE RENAISSANCE}

Much water has flown under the bridge since the Renaissance. The approach that was formed from the scholastic thought of the 12-13th centuries gave a sign of itself in the bottegas of Cimabue and Duccio di Buoninsegna, enrapturing young and talented masters who had shared in the albescent light of the ars Bysantica which permeated the icons, showing the path to the antropomorphistic description of God and to the God-like depiction of man. At one time within each other, above, down and outside, the chrestomathic bases of Western art are connected with the comprehension and depiction of the Sacred. When the Italian humanist Giovanni Andrea, the pope's librarian, invented the term Middle Ages in 1469, he had among other impulses in mind also the new (modern world of Giotto), where the religious devotion found its ground in the new laws of time and space. We live in the illusory space created by the renaissance artists. This is what we believe in and which, through the cosmological fantasies of Copernicus and Kepler, have been given to us, as it were, with mother's milk.

"When an artist begins to paint a fresco, he must depict in his pictures fruit, flowers, birds and nature that constitutes the décor of his work", writes Cennino Cennini as early as the beginning of the 15th century. ${ }^{34}$ And he proceeds there and then: "Through art the natural as well as the spiritual, the real and the fictive open which, in the end, is nothing but the new truth that is being created. Which, at the same time, is both "real life" and fiction, inspiring to speak about art as philosophy. Drawing (Italian: disegno) is a preparation for the system (Italian: compositio), the latter in its own turn for the catharsis-like experience which opens "the window of light and the ladder of the soul", giving the soul an opportunity to rise to the spheres where angels are busy and where "substance which is not distinguished from quality and quality which is nothing other than its own substance is going to be something better - so that finally we come upon a certain act that is utterly pure and measureless." ${ }^{\prime 35}$ Which, as worded like that, forms the opposite to one basic thesis of the Renaissance: everything that we see

34 Cennino Cennini, The Craftsman's Handbook, „Il Libro dell 'Arte“, Vol 1, part 1, transl. by Daniel V. Thompson (New York: Dover Publications, 1954), 2.

35 Marsilio Ficino, Platonic Theology, vol 6, books XVII - XVIII, trans. Michael J. B. Allen, The I Tatti Renaissance Library (Cambridge, Mass; London: Harvard University Press, 2006), 231. 
is also real, everything that appears in the focus of our eye can be reproduced through the rules of art.

Besides the measurable and describable in "A Midsummer Night's Dream", characters appear that in fact should not really exist. Alongside of the thesis "art is truth", an equally valid truth exists - "art is a dream", a dream that was forwarded in its characteristical beauty and multifarious fantasy both by the medieval "Mirabilia", as well as by "Hypnerotomachia Poliphili", sometimes attributed to Alberti. ${ }^{36}$

Beauty is the truth that the artist is able to convey in his/her divine intuition and the human burst of inspiration, and which nobody has been able to measure or to explain. Something that yields the nature that emerges via mimesis into the consciousness of the artist, a new quality in the consciousness of a genius. Revealing himself in the pictures in a mysterious but truthful way, impelling Leonardo besides all of his objective study of nature to see in his output "the execution (operatione), which is nobler than the thinking or science" ${ }^{\prime \prime}{ }^{37}$ Leonardo asks: how does an image emerge?" What happens to the stones in the wall which, despite their seeming separation, form an integral whole on the surface of the picture? ${ }^{38}$ The truth of art is greater than nature could ever offer, the one that we find on the pages of both Vasari's "Vite", as well as in the utterances of the 17th century artists and the opinions of Gian Pietro Bellori and his contemporary theorists of art.

\section{REASON VERSUS FEELINGS}

Too much of a good thing is never good. Excessive emotions, colours, enthusiasm for beauty and for the ability of man to reach through this the deeper sources of truth, is counter-reacted in the 18th century in the form of the enlightenment rationalism, which has made its mark on science as empiricism, and on art in the form of the resistance to the baroque or in Italian, the "contro il barocco". 39 "In architecture a ruthless process of simplification can be observed, leading eventually to even

36 Liane Lefaivre, Leon Battista Alberti's Hypnerotomachia Poliphili: Recognising the Architectural Body in the Early Italian Renaissance (Cambridge, Massachusetts: MIT Press, 1997).

37 Anthony Blunt, Artistic Theory in Italy 1450-1600 (London: Oxford University Press, 1962), 28.

38 Leonardo on Painting: an Anthology of Writings, trans. and ed. by Martin Kemp and Margaret Walker (London, New Haven: Yale University Press, 1989), 222.

39 Contro il barocco, Apprendistato e pratica dell architettura civile in Italia 1780 - 1820, a cura di Angela Cipriani, Gian Paolo Consoli, Susanna Pasquali (Roma: Campisano Editore, 2007). 
more extreme and abstract results, in this case to a symbolic architecture of pure geometry and Platonic essences. ${ }^{140}$ The 18th-century protest movement against emotions can be treated as a kind of new protestant movement, the artistic character of which was the ascetic figurative language, evolved by the imitation of antiquity. "The only way to become great," wrote Winckelmann, "is to imitate antiquity". ${ }^{41}$

Even though today we understand the words of the prophet slightly differently than in the 1750s, now that the excavations of Herculaneum and Pompeii have opened the treasure chamber that for hundreds of years was locked or almost locked for Europe, the idea of the visual culture of the Age of Enlightenment has remained the same. Art is not the private right of an individual genius but, instead, a duty that he/she must inevitably fulfil to culture and the entire mankind. Art becomes a medium that is not so much turned to the spiritual, but which communicates via its normative truth of art with time as history and man as a part of the social system. "Having called under its flags the nations and states, classicism finds itself in the golden cage of its own making. It loses its singing voice and is inevitably forced to withdraw to the position of the grave-digger of the past". ${ }^{42}$ Instead of the immediate impression and mood, the truth of art is determined by the philosophical beliefs of its discourse which, in one way or the other, are connected if not with the iconoclastic negation of depicting nature altogether, then against the direct depiction of this in a way that "supports the ideal of illumination into an Enlightenment faith in clarifying indistinct ideas." ${ }^{\prime \prime 3}$

Yet the art of Enlightenment and its cover, the classicism, that proceeded from the dictate of the classics, are not so monotonous as the traditional science of art has treated it; the logical analysis that centres on organizing the external facts is contradistinguished by the poetry of the Sturm und Drang (literally, Storm and Stress) era, which emphasizes the individual ' $\mathrm{I}$ ' of the artist and the aesthetic experience derived from art. Alongside Winckelmann, Alexander Baumgarten steps forth, the

40 Hugh Honour, Neo-Classicism (Harmondsworth: Penguin Books, 1977), 20.

41 Detlef Kreikenbom, „Verstreute Bemerkungen zur Goethes Anschauung antiker Kunst“, Goethe und der Kunst, hrsg. von Sabine Schultze (Frankfurt am Main: Schirn-Kunsthalle Frankfurt [u.a.], 1994) 31.

42 Juhan Maiste, „Klassitsism ja tõde“, Kunstiteaduslikke Uurimusi, 1/17 (2008), 10.

43 Martin Jay, Downcast Eyes, The Denigration of Vision in Twentieth Century French Thought (Berkeley, Los Angeles, London: University of California Press, 1993), 17. 
notion of "Aesthetica"44 that he revived summarizes and develops further David Hume's, Shaftesbury's views and, more generally, a theory of the English sensual sublime ${ }^{45}$ and the art theory that rose from the notion of the pitoresque, in which the concept of "catharsis" found a visual representation and verbal lexica, suitable to the times. Originality and creative power (Latin: creatio ex nihilo) mark an aspiration towards innovation (the invenzione of the age of the Renaissance), crediting Prometheus with a place of the so-called second creator. ${ }^{46}$ The spiritual revival, of which the constructors of Neo-classicism as a style dreamed of, is accompanied by a continuous conflict between its symbolical message and the verbal message concealed in it, which threatens the era and its message to grope into the semantic jungle which threatens to smother the art into the variety of terms and myriad shades of interpretation. Art and the word, as well as art and religion (truth) may well be talking about the same thing, yet they do so in their own way and according to their own methods. The logical and the aesthetic are part of one another, being expressed in different cognition processes differently, yet both of them carrying in them the seal of truth. "Richness, greatness, truth, clarity, certainty and life of cognition compromise the perfection of every cognition, in so far as they are in agreement with each other in a representation. ${ }^{47}$

In order to recognize beauty, there exist both the way of pure beauty and logics, as well as the way of pure cognition, which in the case of the third important head-word - freedom (German: Freiheit) is on the one hand connected with certain (objective) climatic and political circumstances ${ }^{48}$ but on the other hand, denoting the renunciation of the material

44 The term aesthetics was coined in 1735 by Alexander Gottlieb Baumgarten (from the Greek aisthanesthai, "to perceive") in his dissertation Meditationes philosophicae. Fifteen years later, in the first two volumes of his major work Aesthetica (1750-1758), he established aesthetics as an independent sphere of philosophical inquiry, cognate with, but separate from, the truths of logic and morality.

45 The concept is based on a treatise attributed to Longinus, a Greek philosopher of the third century, "Peri Hypsos", and was originally connected to a literary text only. The revival of the concept in the Europe of the Modern Times is associated with English art, and especially with the names of the leading writers, Richardson and Edmund Burke, who introduced it more widely.

46 Mosche Barasch, Theories of Art 2, From Winckelmann to Baudelaire (New York, London: Routledge, 1990), 38-40.

47 Alexander Gottlieb Baumgarten, Aesthetica (1750), 22. Tsit: The Bloomsbury Anthology of Aesthetics, Ed. Joseph Tanke and Colin Mc Quillan (New York, London, New Dehli, Sydney: Bloomsbury, 2012), 1,161 .

48 Alex Potts, Flesh and the Ideal. Winckelmann and the Origins of Art History (New Haven and London: Yale University Press, 2000), 54. 
and the social:" I observe, that society, merely as society, without any particular heightening, gives us no positive pleasure in the enjoyment, but absolute and entire solitude, that is the total and perpetual exclusion from all society, is as great a positive pain as can almost be conceived. Therefore in the balance between the pleasure of general society, and the pain of absolute solitude, pain is the predominant idea. ... of temporary solitude ... Hence arises the great power of sublime, that far from being produced by them, it anticipates our reasonings, and hurries us on by an irresistible force. Astonishment, as I have said, is the effect of the sublime in its highest degree, the interior effects are admiration, reverence, and respect." ${ }^{\prime \prime 9}$

Art is born on the border of order and chaos and is, as such, already in its essence contradictory, assuming beside imitation also something else that falls under the category of Kant's phrase "disinterested pleasure" (interesseloses Wohlgefallen), which in our world today that is centred on the establishing of oneself, representation and design, tends to stay aside or even be forgotten. Which, however, in the opinion of the author of this writing forms the basic task of art. Irrespective of whether the attribute of the output is language, ear, hand, feet or the entire body. The source of beauty is neither matter nor blood, soil, buds and leaves, nor any mass or matter, but the pure idea that as unobtainable allures both in the big and the little, offering the beauty a principle that is still connected with the visible, yet the real essence of which comes from the most concealed corners of our soul, which is all our own; which does not reveal itself before the external has become internal (and the other way round), finding harmony with the only one whose soul is moved by beauty just to the same extent than it is itself the cause of all beauty.

\section{PICTURE AND WORD}

Throughout ages, the two abilities given to man have enabled us to understand our world, and have enticed us to speak about it in the comprehensible way. To prefer once the one and then the other, to compete in the Age of the Renaissance in literature and art in the form of paragone, and to burn pictures at the time of plundering those. Word is more

49 Edmund Burke, A philosophical Enquiry into the origin of our Ideas of the Sublime and Beautiful with an Introductory Discourse concerning Taste and several other additions by Edmund Burke (London: Thomas M'lean, Haymarket, 1798), 68, 95. 
credible, seeming clearer, more unequivocal, more veracious. The picture, though, is dubious. "I will therefore suppose that, not God, who is perfectly good and the source of truth, but some evil spirit, supremely powerful and cunning, has devoted all his efforts to deceiving me. I will think that the sky, the air, the earth, colours, shapes, sounds, and all external things are no different from the illusions of our dreams, and that they are traps he has laid for my credulity; I will consider myself as having no hands, no eyes, no flesh, no blood, and no senses, but yet as falsely believing that I have all these." ${ }^{50}$ The complement of life is a fantasy, everything that we dream of and all that we perceive as visual illusions. "It must be nonetheless admitted that the things we see in sleep are, so to speak, painted images, which could not be formed except on the basis of a resemblance with real things." ${ }^{\prime 51}$

Word and language - both of them are guides to truth, although expressing this very differently, giving in the18th century philosophy of language the role that considered poetry the so-called mother tongue of the human race. In their primary meaning, the things and words were attached to one another and not differentiated, it was only when the civilization started to thrive that the language began to crumble from the things, to become independent and to solidify into the system of human conventions. ${ }^{52}$ Which of the two ways of expression - visual and verbal - is still better, more reliable, more veracious?, asks Lessing. Why does Laokoon shout in poetry but does not shout in marble?, asks Lessing. But because of the fact that poetry is not only better, but also more exact, even questioning one of the basic trumps of the art of painting, namely "that her composition must be regarded as invisible." ${ }^{53}$ Only poetry is able to convey all different nuances of emotion, to speak directly, to bring to the surface the emotion that uncovers the deepest stratifications of the human soul.

Language and the philosophy of language make the phonetical-ritual process observable and describable, changing the language into the social instrument of communication, and the latter in its turn an object in various linguistic studies and experiments, staying almost aside,

50 René Descartes, Meditations on First Philosophy with Selections from the Objections and Replies, trans. by Michael Moriarty (Oxford, New York: Oxford University Press, 2008), 16-17.

51 Ibid., 14.

52 Jaan Undusk, „Paradiislik keel: jalutuskäik Hamanni ja Goethega“, Keel ja Kirjandus, 7 (1994), 386.

53 Gotthold Ephraim Lessing, „Laocoön“, The Bloomsbury Anthology of Aesthetics, ed. Joseph Tanke and Collin Mcquillan (New York, London, New Delhi, Sydney: Bloomsbury. 2012), 214. 
a thing-in-itself, which is separated from the subject by a barrier of misunderstanding. The hope that we get out from the labyrinth via language where the pith of the human soul is hiding itself, leads us rather back to the labyrinth which no surgeon has been able to open, not with the sharpest of scalpels. Or, as Johann Gottfried Herder has put it: "Should physiology ever progress to a point where it can demonstrate psychology - which I greatly doubt - it would derive many a ray of light for this phenomenon, though it might also divide it in individual, excessively small, and obtuse filaments. ${ }^{254}$ One can only think what one can express linguistically, we are able to achieve non-empirical concepts by of a sort of metaphorical extension from the empirical ones.

But what is metaphor? What is language? asks Herder. Being definable by abstractrational categories, the language itself remains agnostically elusive, presenting us with the concepts of space, of form, and of colour (Begriffen der Raum, Gestalt und Forme), being a teacher and a muse at the same time." ${ }^{55}$ In the reality of this being, it is impossible to ever understand language thoroughly, to find its unique roots. Everything we see, strength hand saps (German: Säfte) ${ }^{56}$, do indeed belong to the roots that communicate with us, yet in their own metaphysical language. "The symbolic sources of language, however, remain inevitably hidden for the eyes of the examiner, opening in the artistic reality through the art itself.

Besides Johann Georg Hamann, the influence of Herder's theory of aesthetics on the contemporary theory of art is hard to overestimate; touching, at the same time, the both sides of it - the analytical approach of Ludwig Wittgenstein, as well as the phenomenological approach of Maurice Merleau-Ponty. Perception is connected with senses and the reception of these in the intellect. However, concerning the roots, then those are in so deep the earth, through which no one has ever succeeded to see."For this reason, even the most refined operations of the soul have been given names native to sight and hearing, as it is shown by the terms of intuition and ideas, fancies and images, representations and

54 Johann Gottfried Herder, „Essay on the Origin of Language“, trans. by Alexander Gode, On the Origin of Language (New York: Frederick Ungar Publishing Co., 1966), 87-88.

55 Ibid., 91.

56 Johann Gottfried Herder, Abhandlungen über den Ursprung der Sprache, welche den von Königl. Akademie der Wissenschaften für das Jahr 1770 gesetzten Preis erhalten hat. SuD Müller Bd. 1130. 
objects, and a hundred others beside." "W7 "What lies before my eyes"? And Herder answers this unequivocally. "Our whole life, then, is to a certain extent poetics: we do not see images but rather create them. The Divinity has sketched them for us on a great panel of light, from which we trace their outlines and paint the images of the soul using a finer brush than that of the rays of light." 58

As much to the ancient people, the rainbow is a mystery to the contemporary people as well. The celestial light and the inner light belong together, what is different is the form they are conveyed, of which throughout the aesthetic thought of the 19th and 20th centuries the same theses are voiced concerning the world, its interpretation, translation, mind, history and God. The word, however, is preferred as usual, which, besides the picture, music and dance, marks a general method, through which the rest of the muses cannot be unclothed though, then at least it is possible to describe their costumes that the diligent maidens have been weaving of golden and silver threads throughout the whole year. They do this once in a year in order to mount the Acropolis hill and to cover the body of the virgin Athena with the ritual peplos. The medium between the world and us is the human language that Herder considers to be more essential than any other means of communication, retelling an ancient myth in order to make it more expressive -a legend of Aesop, in which the clever fox learned the human language and became a friend; the stupid wolf, however, remained as stupid as before. ${ }^{59}$

\section{ART AND THE ART SCIENCE}

Herder was the pathfinder. According to him, the question was raised whether interpretation was a science or an art. Despite the points of contact between arts and natural sciences, the two approaches differ -the subject-oriented one characteristic of humanities (Latin humanes, human) and the object-oriented (nature) one, central already in Herder's own writings. Which makes the reduction of one into the other not only complicated but in several ways just senseless. All this without excluding the survival of Hegel's ideas in both of them, of which the one guides to

57 Johann Gottfried Herder, „On Image, Poetry and Fable“, Selected Writings on Aesthetics, transl. and selected by Gregory Moore (Princenton, Oxford: Princenton University Press, 2006), 355.

58 Ibid., 158.

59 Herder, Abhandlungen über den Ursprung der Sprace, 156 
the physical materialism, and the other - to the subject-centred philosophy -to Schleiermacher, Frege, and from there further on to Husserl and his school of hermeneutics, offering the key for opening the semantic character of the word via the semiotic system that emerged in the $20^{\text {th }}$ century as an independent theory of information. Semantic meanings or concepts are word-usages, in order to reproduce the target of language as a concept from which the translator should take the most closely corresponding word to mark the fabric of different facts - both natural and cultural, "the art world" in all its expansions from the music of stars to the silent music produced by the inner voice of the soul, "where the cognition as the existential vehicle of life, remains geometrically and cosmically separated from the absolute power of consciousness until the forces of cosmic architectonics." ${ }^{\text {}} 0$

While taking a look at the spaciousness of the aesthetical thought of today, the differentiation of two distinct approaches catches the eye the formal-analytical and ideological -philosophical ones in a way that turns the idea into " an object in itself in Plato's heaven, distinct from things in brain, leaving still unresolved the fundamental question of Kant" whether a concept in the brain is something in the head of the individual thinker or whether it is something that is in some sense shared between several thinkers." ${ }^{\prime 1}$ Thus it seems that we are as far as we were at the very beginning. The ontological and cognitive sides are separate. The basic question - who we are and how we can speak of ourselves is still unresolved in the conventional language of science. Which does not mean though, that we could not or should not seek answers to the questions that were central already in the aesthetical thought of Herder and, why not, in the intellectual vision of Karl Morgenstern, who stands closer to us both geographically and via the history of culture, when he spoke about two different possibilities - to understand and describe art - spoke about aesthetical idealism (ästhetischer Idealismus) and aesthetical realism (ästhetischer Realismus) ${ }^{62}$ In the beginning of the 19th century

60 Anna-Teresa Tymieniecka, „Transcendentalism Overturned. Life's Geo-Cosmic Positioning of Beginnings", Transcendentalism Overturned. From Absolute Power of Consciousness Until the Forces of Cosmic Architectonics, ed. By Anna-Teresa Tymienicka, Analect Husserliana, The Yearbook of Phenomenological Research, Vol. CVIII (2011), 3 pp.

61 Christopher Gauker, Words and Images. An Essay on the Origin of Ideas (New York: Oxford University Press, 2011), 5.

62 Karl Morgenstern, Einleitung zur Ästhetik. Mit Andenkungen zur Geschichte derselben (Dorpat, 1815), 6. 
Tartu, both have a right to speak - science as well as art, modus logicus as well as modus aestheticus which, while shaping the spirit of the era, are the expression of the style (le style c'est l'homme) invented by man in word and in picture.

When in the practical science the two stand if not light years apart, then at least at a distance measured by years in history. In the philosophical kind of approaches, however, it is the problem that is in the central focus, allowing one to assert that "...the analytic tradition's inquiry into language has led it repeatedly to experience the failures and paradoxes in its attempt to envision language as a total structure of signs", which in the case of the critical approach of Heidegger questions "the consideration of "rule following" and the idea of the "private language"'", offering instead a connection in between the ordinary language and the metaphysical assumptions that underlie it, assembling these thereupon in the sentence "Being and Time as Dasein", which has for a long time determined the life of the human being as the subjectivity of the subject of experience." ${ }^{\prime \prime 3}$ In the science of art, too - as the discipline dealing with the visual art has been called to this day, time has raised the same problems which, true enough, have never attained the full clarity and philosophical depth of thought of linguists, yet have given the ground for a new discussion.

Which has caused one to reread Winckelmann's texts with a new glance, to find in them the emotional point, to talk of him as a poet, so that besides all the infatuation of the system to bring forth "an objective subject that almost satisfies its subjective object." ${ }^{\prime 64}$ Connecting art history via history of art with the approach that centres on the object-subject oriented phenomenology. "Art cannot be explained", is a thought that stems from the era of modernism, being connected with a maxim of Wittgenstein: "What we cannot speak about we must pass over in silence." ${ }^{\prime 65}$, which does perhaps sum up the existentialist theory of art of the last century better than long sentences and quotes do. Only a fool can ask what art is, as I remember the admonition of the authorities, accom-

63 Paul M. Livingston, Philosophy and Vision of Language, Routledge Studies in Twentieth-century Philosophy (New York, London: Routledge, 2010), 148-149.

64 Whitney Davis, "Winckelmann Divided: Mourning the Death of Art History", The Art of Art History: A Critical Anthology, ed. Donald Preziosi (Oxford, New York: Oxford University Press, 1998), 48. 65 Ludwig Wittgenstein, Tractatus Logico-Philosophicus / Logisch-philosophische Abhandlung, (Side-by-Side-by-Side Edition, version 0.21, 2010), 111: http://people.umass.edu/klement/tlp/tlp.pdf (viewed on 08 July 2014) 
panied by a mental swinging of the finger. Let's get down to business: talking of text, context and facts. Compared with word and language which have been the favourites of the humanities since the reformation, offering the artefacts a welter of explanations, and often different ones, art in its primordial meaning has remained as inexplicable as in the times when Pliny put down the biographies of the first artists. Our research has not advanced the science of art. And in my view, for one simple reason -"the archaeologists of culture" have simply been digging on the wrong spot, attempting to transfer the scientific and linguistic experience mechanically to the visual which, as repeatedly emphasized in this article, belong both to man and are partly in his service as well, yet expressing the world and us as differently as the eye and tongue do.

We are standing at the point where we cannot say much more of a picture than it is either beautiful or very beautiful, impressive or less impressive, we like it or we do not like it, in order to continue the conversation about the author and the political conditions of his time, the colours, canvas and what they cost - thus everything exterior in relation to art as the unique medium of perceiving the truth and declaring this. We can talk about a work of art but not about art, give lectures and write books, create ever new treatments, connecting these with history as an independent genre with the most diverse dimensions, treating thus the art within the disciplinary system of art history - in the framework of its own theoretical system and methods. It is the history of art that makes art understandable, which selects, conceptualizes, divides into themes and subthemes, establishes periods and concepts of style within the rights of its own paradigms of science which is connected "with methodologies of other humanitarian studies from semiotics to psychoanalysis - as developed largely in literary theory, which has been in turn deprecated in comparison with advances in literary fields." ${ }^{\prime 66}$

The theory of art is a theory that deals with the comparison and analysis of images and pictures, offering within the help of scientific categories (historical-documentary, iconological, colour theory and the physical spectral analysis) an opportunity to create ever more exact and factual narratives, yet failing thereby to open the deeper essence of the explosion of art. Which, according to Kant and, for example, also

66 Roman Frigg, Matthew C. Hunter, Beyond Mimesis and Convention: Representation in Art and Science (New York, Berlin: Springer Verlag, 2010), xxi. 
Derrida, opens itself rather as a sublime feeling that cannot be described with words than within the discipline of the history of art, that has been described as close relations with the literary traditions, the bearers of which are both the tradition of $U$ t Picture poesis and, more recently, the connections made in the late nineteenth and twentieth centuries between art history and the field of philology (a privileged discipline in Germany). ${ }^{67}$ Which, when retracting art into a verbal text, is indeed able to explain what takes place around art, incorporating in the discussion the approaches of several side-branches "that might be imported into an impoverished area." ${ }^{\prime \prime 8}$ Creating in this form a somewhat illusory feeling in the receptant, as if the art itself were a part of the original reality, that as the value of truth is a part of our view of the world, guaranteeing us the understanding of both art itself, as well as the output and its sources. There is a significant difference between art and science."Science manipulates things, but refuses to live among them," writes Maurice Merleau-Ponty, and continues: "Art, to be more exact, the art of painting, obtains its subject exactly from the rank of this rude mind which in its activeness does not want to know anything." ${ }^{\prime 6}$

Thus the history of art has its place and the culturally determined room besidethe other mental activities. Art and picture, however, unfortunately do not. As centuries before, art with its imaginary spacial construction and the language of images creates instability. Thanks to the illusion of reality installed into it by the artist, it does on a certain level seem to be embraceable and understandable, while on the other one - the substantial level, it remains equally incomprehensible. We need a new history of art, that would connect two different realities, which would be at the same time both science, as well as religion, the estimated parameters of which would not just be narrative or social, technical or institutional, political or historical but, instead, connected with the main task of art - to give back to the history of art its place which would allow it to have its say in the yearning for the beautiful and the good. The mission of the history of art is greater than the paraphrasing and interpreting the events of the past. The history of art is lost, but art his-

67 Mark A. Cheetham, Kant, Art, and Art History. Moments of Discipline (Cambridge, New York: Cambridge University Press, 2001), 21.

68 Mieke Bal, Quotaing Caravaggio: Contemporary Art, Presposterous History (Chicago: University of Chicago Press, 1999), 6.

69 Maurice Merleau- Ponty, "Eye and Mind", The Merleau-Ponty Aesthetics Reader:Philosophy and Painting, ed. by Galen Johnson (Evanston: Northwestern Western University Press, 1993), 121, 123. 
tory is still with us; and although art history often attempts to bring the object back to life, finally it is our means of laying it to rest, of putting it in its history, and taking it out of our own, where we have witnessed its departure. ${ }^{\prime 70}$

\section{ART IS A TITMOUSE ...}

Art is a titmouse that flew on the window of the poet, "white its neck and the belly yellow" (Juhan Liiv). Or, according to another poem, "Swallow, white is your belly, and black is your back", as the lines in the ancient Greek song of the swallow and crow run. ${ }^{71}$ The answer to the question whether words can become the equivalent of the picture in the language would be definitely just one: yes, they can. It is another matter though, in which form or which way. Being a historian of art, according to my trade licence - so to say, "a natural born art historian", I do think that the history of art as a discourse is, due to its methodical variety, sufficiently extensive as to enable me to deal with both the pictures and their frames, as well as the books on art, for the rest of my life. This in the area of both aesthetics and the history of art. The situation, however, will become more complicated at the moment we face the picture alone, just the two of us - when catharsis touches both the spirit and the body - while listening to "Für Elise" one would ask how on earth it would be possible to translate it into words. Everything is just a dream, is a sentence by Gustav Suits. An artefact cannot be explained in any other way than by reviving an affect once again. This is a fact that a scientist has to acquiesce in, at least for the time being. A picture is nothing but the truth, the content of which would not open either before or after the picture itself, but within the picture, in which case the frescos of the Sistine Chapel or the suprematistic black square on the white and the white square on the black surface by Malevich are of the same value, and possibly even of the same meaning, referring both to the Creator, our Maker, as well as to the universe.

Art and truth are words that have for years in me, as well as for thousands of years in a considerably wider circle of the humanities, evoked thoughts, of which one could ask with the following words of

70 Davis,"Winckelmann Divided", 50.

71 "Pääsukese ehk vareselaul”, transl. Janika Päll, Vanakreeka kirjanduse antoloogia (Tallinn: Varrak, 2006), 108 
Fig. 5. Jaan Toomik, "Family". Canvas, acrylic, 2014. Photo by Stanislav Stepashko.

Goethe:"wie viel unser Selbst und wie viel die Außenwelt zu unseren geistigen Dasein beitrage?" "How much do we by ourselves and how much does the external world contribute to our spiritual existence?" There is no answer to this. However, there is a method, according to which "... the art of poetry and comparative natural science are so closely related, while they both are subjugated to the same faculty of judgement."72 When choosing the imaginary approach instead of the conceptual one, we do draw back from the main road where traditionally the linguistic communication has been treated as a means which reveals to a hearer the conceptual content of an underlying thought which, however, in the form of the finally shaped sentences is but a part of our picture of the world, which, in addition to the word, the other senses, too, help to create. The latter, though, that help to create sentences as a result of a certain logical process, consist at the same time, first and foremost, of images that we touch when chasing them, touching not so much the argumented thoughts that have been shaped into words and their corresponding meanings as Gottlob Frege described them - semantics,

72 Johann Wolfgang Goethe, „The Influence of Modern Philosophy“, trans. Douglas Miller, Scientific studies/ Johann Wolfgang von Goethe, vol 12 (New York: Suhrkamp, 1988), 128. 
Fig. 6. Jaan Toomik, "Family tree". Canvas, acrylic, 2014. Photo by Stanislav Stepashko.

iconology and semiotics, that have to a considerable extent determined the contents of the history of art as a science since the 19th century, by the nonconceptual, imagistic cognition through which the truth reveals itself in word without meaning. ${ }^{73}$

73 Gauker, Words and Images, 14. 
This allows us, while approaching art, an opportunity to see behind the invisible, to talk about the things that perhaps the artist himself/ herself has not been conscious of, through which energy assembles as monads in the starry sky, forcing us to lift our heads from among the facts to the ideas, and to look for ever new and more precise equivalents among the poetic images. One poem may express more than the whole book written in prose: "The historian and poet differ from each other not because one of them writes verse and the other one prose, for ... also Herodotus could be put into verse, but it will still remain history, whether in verse or prose, but because the historian relates what happened, the poet what might happen. That is why poetry deals with general truths, history with specific events". ${ }^{74}$ Two different approaches to the subject in the science of art have enabled already since the 19th century to walk, so to say, on two feet at the same time, one of which leads to the concrete empirical history of art, the other one to the theory of art that springs from the discourse of ethics, first emerging in the writings of Carl Just, Anton Springer and Hermann Grimm, which brought along the rebirth of the history of art in the works of Max Dvorak and Alosis Riegl, uniting into an integral whole the writing on art that corresponded to the ideals of humanistic culture, which is also familiar with both the positivistic and fact-centred approaches, and the suggestive mythologization of the so-called romantic "great man" (genius - J.M.) ${ }^{75}$

Art is both a revelation, as well as palpable reality. "For Kant, no worked structure is an artwork unless it creates and maintains, and the free play for a purely intellectual and cognitive enjoyment. Consequently, art production necessarily involves the invention of Works that have sufficient complexity and sufficient openness to stimulate a rich train of thought, a set of plausible readings that must always remain indefinite." 76

Art is both spirit and flesh, holy relic and vision, the holy yearning hidden in the painting rendering the scene of Jan van Eyck's "Adoration of the Lamb" a radiantly sublime colour, and the particular feeling of happiness which, as a halo above the head of Our Savior, are both the

74 Aristotle, On Poetry and Style, 1551bI-b5, trans. G.M.A. Grube (New York: Macmillan, 1987), 18.

75 Johannes Rössler, Poetik der Kunstgeschichte. Anton Springer, Carl Justi und die ästhetische Konzeption der deutschen Kunstwissenschaft (Berlin: Akademie Verlag, 2009), 5.

76 James Elkins, Art History versus Aesthetics (New York: Routledge, 2006), 6. 
truth and the prayer at the same time. While standing alone in front of the picture, we know exactly that on the right hand is our way to Elysium, the left hand takes the wicked to Tartarus. The lambs remain to the right side of Christ and the goats to his left side (Matthew 22:35). The truth, however, is on both sides. For there is no absolute darkness, there are only the places that have not been lighted as yet. In the pictures of Olev Maran, art and truth are present at the same time. Art renders light to a picture.

Juhan Maiste: Art And Truth

Keywords: Art, Truth, Art History, The Analytic Versus The Phenomenological Approach

SumMary:

Art and truth are the two different beginnings of understanding our world, two possibilities that the artists themselves, as well as the authors of art history, often treat if not as opposite, then still as different in their fundamental essence. Mostly proceeding from the Platonic conception of idea (eidos) and form (morphe), the creation of the world of God and the creation of the world of man appears to us in the form of the piece of art what one can see and use but never understand in its final meanings and essence. Art is an attribute of idea, while truth in its turn is more profound than art, leaving art rather an illustrative role. The prerequisite of writing about truth is its logical foundation which, as the starting point of the epistemological side, prefers logical explanation, through which the output of the author finds its place via the historical narrative or its semantic significance, being associated rather with the world that surrounds art than with art itself. According to this the non-epistemological fictional reality of art is given to us by different representations, while the truth remains to us a secret and a sort of Pandora's box that nobody has yet been able to open.

The present article should be understood as a quest that seeks to bring forth art's actual nature from the shadow of different techniques, icono- 
logical approaches, political and social context, focusing in so doing on art as the unity of the external and the internal, including thereby the invisible and indistinguishable immaterial plasma, as well as the connected reflection in the form of a visual image. At the same time, the author of this essay understands the discrepancy and the complicated nature of his aim. The article should be interpreted as a sort of search or then a pilgrimage into the depths of different opinions and evaluations of artistic reality, defining it from Aristotle to Plotinus, and from Kant to the new possibilities of phenomenology of the 20th century of Heidegger and Derrida. The aim of this article is to take under the observation and hesitation the methods achieved by the so-called "critical art history", and instead of mourning the "art history" as a discoursive paradigm, to speak in the benefit of the new "history of art" where the pieces of art (artefacts) appear to us as fresh corals lifted up from the bottom of the ocean. As a sort of revelation art gives birth both to poetry and which, since Herder, has been characterized as the metaphysical and inexplicable essence of the image - as something that is born out of the darkness of fantasy opens as light on the paintings of Olav Maran, William Turner or Jan van Eyck. The precondition of understanding art is not a trace in memory (eidòlon) or an image (eikòn), but the idea itself, which does not appear before or after the facts but simultaneously with them, thus opening the deeper contents of our psychological subconsciousness, flowing out as ergon in any work of art. And not anywhere else - neither above nor below, right or left. Art and truth are two different sides of the one and the same phenomenon - the world as a piece of art, which can be experienced and understood time and again through the ability given to man to understand the world within the limits that we are able to understand. This makes the understanding of art both complicated and simple, seeking not so much the proof than the enlightening experience.

Without offering practical instructions and suggestions as to how we should recognize art or to write about it, the author of this essay has rather expressed his concern about the conventional approach to the history of art today which, while constantly approaching science, has deprived art of its most essential part. Having alienated from the magical cathartic feeling of the touch of the genius, which is mediated rather by the emotions of joy and sorrow, good and bad, beautiful and ugly, which we use anyway as our fundamental tools describing and perhaps 
understanding the world and ourselves. Having changed the universe (Greek: apeiros) into cosmos, we have been able to weave the warp into the fabric of art and art facts, yet without understanding the meaning of single forms which are born again and again between the light and myself as the recipient of light. As much as art can be the twin sister of science, it is a part of the human soul and the divine spirit which, as the religious recognition, will open itself only to those who themselves are ready to open themselves to it.

CV:

Juhan Maiste is professor and Head of Departement of Art History at the University of Tartu. As a prolific writer he has authored a large number of monographs and articles on architecture, classicism, cultural heritage, the philosophy and poetics of art history. Also among his scholarly interests have been Estonian and Livonian manor architecture, the phenomenon of park landscapes as well as the work of Johann Wilhelm Krause. In addition to teaching and research, professor Maiste curates the publication of the Baltic Journal of Art History. 
